\title{
Novel foraging strategies observed in a growing leopard seal (Hydrurga leptonyx) population at Livingston Island, Antarctic Peninsula
}

\author{
Douglas J Krause ${ }^{1,2^{*}}$, Michael E Goebel ${ }^{1}$, Gregory J Marshall ${ }^{3}$ and Kyler Abernathy ${ }^{3}$
}

\begin{abstract}
Background: Leopard seals are apex predators that can alter the community structure of Antarctic coastal ecosystems. Previous behavioral studies were limited to land-based, daytime observations of foraging leopard seals. Consequently, foraging tactics, social behaviors, and indirect ecosystem impacts are poorly understood. Here, we present the first analysis of animal-borne HD video footage for foraging leopard seals. Each CRITTERCAM was deployed with Fastloc GPS and time-depth recorder instruments providing fine-scale habitat context for observed foraging behavior. We analyzed seven deployments obtained in January and February of 2013 and 2014 from adult female leopard seals near mesopredator breeding colonies on Livingston Island, Antarctica.
\end{abstract}

Results: The average deployment length was $4.80 \pm 2.45$ (range 0.86-9.12) days, which covered a total of 16 foraging trips. Habitat use, along with 39 prey capture attempts, and 11 leopard seal social encounters were scored from $50.3 \mathrm{~h}$ of video data. We obtained 3,833 post-filter GPS positions, accurate to within $70 \mathrm{~m}$, and the mean dive depth was $14.84 \pm 8.98 \mathrm{~m}$. Leopard seal foraging focused on four prey items: Antarctic fur seals, Antarctic fur seal pups, pygoscelid penguins, and demersal notothen fishes. Ambush tactics used only by a subset of leopard seals drove high capture success rates of fur seal pups. We identified novel prey-specific foraging tactics including stalking and flushing notothen fishes.

Conclusions: Leopard seals have been described as generalist apex predators; however, video and movement data suggest that leopard seals employ specialized prey-specific hunting tactics. Although preliminary, our findings indicate that leopard seals can affect coastal ecosystems through pathways beyond direct predation, including intraspecific kleptoparasitism and facultative scavenging/food caching. Our results suggest that position-integrated video data will be vital in quantifying the ecological impact of this abundant and versatile apex predator.

Keywords: Leopard seal, Apex predator, Hunting tactics, Kleptoparasitism, Food caching, Scavenging, Fastloc GPS, CRITTERCAM, T-LOCOH

\section{Background}

The foraging behavior of apex predators can alter marine coastal ecosystems through direct and indirect pathways of predation [1-3]. Leopard seals (Hydrurga leptonyx) are large, abundant, top predators with a circum-Antarctic

\footnotetext{
${ }^{*}$ Correspondence: douglas.krause@noaa.gov

${ }^{1}$ Antarctic Ecosystem Research Division, NOAA-NMFS-SWFSC, 8901 La

Jolla Shores Drive, La Jolla, CA 92037, USA

Full list of author information is available at the end of the article
}

distribution [4]. They can directly reduce Antarctic fur seal (Arctocephalus gazella) population abundance through predation of pups $[5,6]$. Intense predation has also been reported at some penguin breeding colonies $[7,8]$. Though not examined to date, leopard seals likely affect coastal ecosystems through pathways other than direct predation as well [9]. For example, leopard seals may compete with sympatric mesopredators (e.g., penguins or fur seals) for common prey resources, or 
perceived predation risk may reduce mesopredator fitness [10-12]. Despite the potential for leopard seals to control prey populations and affect trophic pathways through top-down forcing, their prey and non-prey interactions are not well studied.

Leopard seal research has largely focused on identifying top-down ecosystem effects through direct predation. Reports of leopard seal diet in the western Antarctic Peninsula (WAP) indicate that Antarctic krill (Euphausia superba), crabeater (Lobodon carcinophagus) and fur seal pups, penguins and myctophid fish are key prey items [13-16]; however, observations were often contradictory. Previous studies of leopard seal predation on fur seals $[13,17,18]$ and penguins $[8,19-22]$ were informative, but limited to opportunistic, land-based, daytime observations. Accordingly, the preferred prey items, hunting tactics and success rates of leopard seals are poorly known.

Describing the social behaviors of predatory carnivores can also be vital to understanding their ecosystem impacts [23-25]. For example, while some carnivores hunt alone, others employ an array of cooperative strategies which can affect prey choice and capture success rates [26-29]. Interference competition can also affect ecosystems by forcing predators to expand their foraging habitat, alter their target prey, or increase their hunting effort [30,31]. Intraspecific competition, in particular, is often intense due to the high likelihood of niche overlap [32, 33], and is characterized by aggressive behavior [9]. For leopard seals, agonistic interactions, evidence of cooperative hunting, and other social behaviors have been difficult to describe and confirm [17].

Despite their ecological relevance, focal studies on leopard seals have been hindered because the seals are difficult to access and observe. Leopard seals are solitary $[34,35]$ and are typically associated with remote marginal pack ice habitat [36-39]. The recent loss of sea ice in the WAP, due to rapid regional warming [40-42] has forced a redistribution of resident Antarctic ice seals [43]. It is likely that these regional movements have driven the growing number of leopard seals to predictably haul out on land at Cape Shirreff, Livingston Island (US-AMLR unpublished observations ${ }^{\mathrm{a}}$ ). And, while opportunistic surveillance is temporally restricted and land-based observations are not well suited to marine predators that are often submerged [44], animal-borne video data have allowed the description of prey selection [45], habitat use $[46,47]$, foraging tactics [48-50] and community interactions [51] for predatory phocids. Predictable haul-outs and animal-borne video have allowed unprecedented access to free-ranging, adult leopard seals.

The integration of high-resolution animal-borne GPS, time-depth, and video instruments provides an opportunity to describe the hunting and social behaviors of vertebrates. Historically, utilization density maps of low-accuracy animal movement data have been helpful in identifying key foraging habitat [52] and time-at-location or movement-based models have identified foraging strategies [e.g., 53-55]. Overwhelmingly, though, movement models and home range estimators have considered foraging area, spatiotemporal interactions, and animal movement separately [56]. Fortunately, Fastloc GPS technology integrated into animal-borne tags [57] has facilitated the collection of accurate at-sea positions [58] collected at regular, frequent intervals [59]. These timeintegrated, GPS data sets [60] motivated the creation of analytical techniques [61], such as the non-parametric Time Local Convex Hull (T-LoCoH) kernel approach, that can simultaneously address area use and movement on ecologically relevant time scales [56, 62].

We use this integrated video and spatial approach to quantify and describe leopard seal prey selection, foraging tactics, habitat use, and intraspecific social interactions.

\section{Methods}

Research was conducted at Cape Shirreff $\left(62.47^{\circ} \mathrm{S}\right.$, $60.77^{\circ} \mathrm{W}$ ) on the north shore of Livingston Island (Fig. 1). Bounded by glaciers to the south, the Cape is approximately $3 \mathrm{~km}$ long and $1.5 \mathrm{~km}$ wide. Within 2 nautical miles $(\mathrm{nm})$ of the shoreline the bathymetry is shallow $(<100 \mathrm{~m})$. Offshore it slopes down to a characteristically narrow, deep ( $>400 \mathrm{~m})$ continental shelf break [63] approximately $50 \mathrm{~km}$ to the north. The shelf break is historically associated with the southern boundary of the southern Antarctic Circumpolar Current front [64], which concentrates Antarctic krill [65]. Access to these reliably productive foraging grounds and the Cape's icefree beaches has facilitated abundant, krill-dependent pinniped and seabird breeding populations (Fig. 1). The US Antarctic Marine Living Resources Program (USAMLR) field camp at Cape Shirreff serves as a base for a multispecies, long-term ecological monitoring program focused on using Antarctic fur seals and gentoo (Pygoscelis papua) and chinstrap penguins (Pygoscelis antarctica) as indicator species. These studies are designed to provide indices which inform management of the regional krill fishery through the Antarctic Treaty system [CCAMLR Ecosystem Monitoring Program (CEMP)]; [66].

Despite this concentration of multiple potential prey resources, regular surveys never reported seeing more than two leopard seals at Cape Shirreff before 1996 [5]. However, the number of leopard seals has been steadily increasing since that time [67]. Leopard seals haul out on Cape Shirreff beaches annually between December 


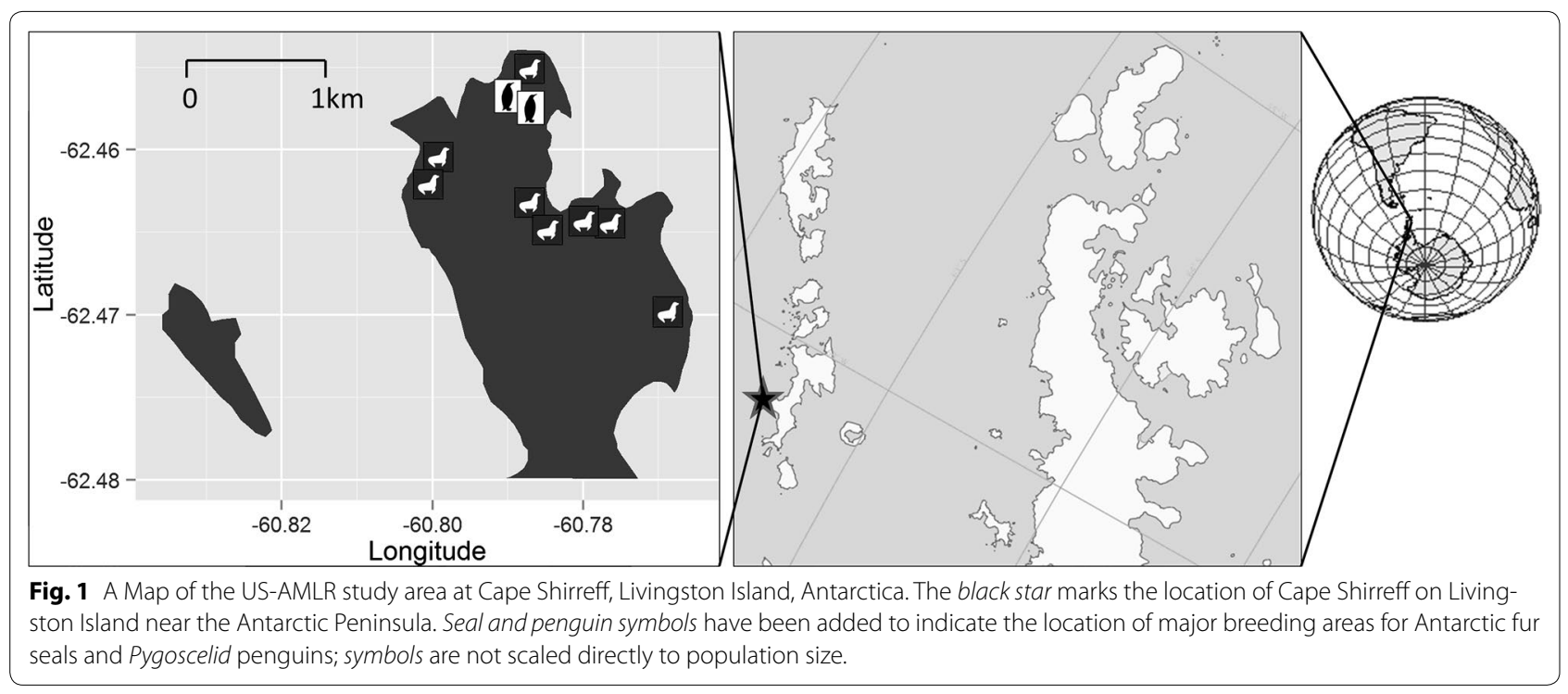

and June with peak densities in January [range 22.7-54.5 seals/nautical mile $(\mathrm{nm})^{2}$ ] and February (range 20.5-38.7 seals $/ \mathrm{nm}^{2}$ ) (US-AMLR unpublished observations). While haul-out densities may underrepresent the number of leopard seals present within a survey area [68], they do provide a minimum reference estimate. The densities of adult female leopard seals hauling out at Cape Shirreff are two orders of magnitude higher than reported elsewhere in the Antarctic (range 0.01-0.521 seals $/ \mathrm{nm}^{2}$ ) [37, $39,69]$. Based on incidental observations and scat analysis, leopard seal predation on fur seal pups and penguins is common between December and March ([18], USAMLR unpublished observations), but it has been difficult to quantify.

Healthy, adult, female leopard seals were selected for this study in January and February of 2013 and 2014
(Table 1). A National Geographic CRITTERCAM video instrument [Generation VI, or Micro-marine, settings in Additional file 1, $720 \times 1280 / 30$ frames per second (fps), color video, [70]], a time-depth recorder [Mk9 $(67 \times 17 \times 17 \mathrm{~mm}, 30 \mathrm{~g})$, Wildlife Computers, Redmond WA, USA, sample rate: $60 \mathrm{samples} / \mathrm{min}$; or National Geographic CRITTERCAM VI, Washington D.C., sample rate: 60 samples/min; or DST-Milli-TD/100, Star Oddi, Gardabaer, Iceland, sample rate: 12 samples/ min], a Fastloc GPS instrument [SPLASH 10-AF-297A $(86 \times 55 \times 26 \mathrm{~mm}, 130 \mathrm{~g})$, Wildlife Computers, Redmond WA, USA; or F2G134A $(58 \times 35 \times 18 \mathrm{~mm}, 38 \mathrm{~g})$, Sirtrack Ltd., Havelock North, New Zealand] set at the maximum acquisition rate, and a VHF transmitter (Advanced Telemetry Systems, Isanti, MN, USA) were attached to the forward-dorsal mid-line pelage using Devcon 5-min

Table 1 Individual leopard seal deployment details and hunting tactics

\begin{tabular}{|c|c|c|c|c|c|c|c|c|}
\hline Animal ID & $\begin{array}{l}\text { Deployment } \\
\text { date }\end{array}$ & $\begin{array}{l}\text { Deployment } \\
\text { length (d) }\end{array}$ & $\begin{array}{l}\text { Dive depth } \\
\text { (m) }\end{array}$ & No. trips & Mass (kg) & $\begin{array}{l}\text { Standard } \\
\text { length }(\mathrm{cm})\end{array}$ & Carcass & $\begin{array}{l}\text { Target prey- } \\
\text { hunting tactics }\end{array}$ \\
\hline $406 Y$ & January 8, 2013 & 9.12 & $12.2 \pm 8.2$ & 4 & 498 & 312 & 4 & $\begin{array}{l}\text { 2-ambush, 4- } \\
\text { chase, 3-chase }\end{array}$ \\
\hline $394 Y$ & February 1, 2013 & 4.69 & $13.1 \pm 6.5$ & 2 & 416 & 285 & - & - \\
\hline $422 Y$ & January 12, 2013 & 0.86 & $14.1 \pm 9.3$ & 1 & 416 & 293 & 2 & 2-ambush, 3-chase \\
\hline $397 G$ & January 16, 2014 & 5.82 & $14.6 \pm 10.5$ & 3 & 385 & 289 & - & 2-ambush \\
\hline $160 R$ & February 12, 2014 & 4.65 & $17.7 \pm 12.2$ & 1 & 494 & 311 & - & 1-chase, 2-chase \\
\hline $401 Y$ & January 14, 2014 & 4.12 & $16.1 \pm 8.6$ & 2 & 485 & 301 & 2 & $\begin{array}{l}\text { 1-chase, 3-flush } \\
\text { and stalk }\end{array}$ \\
\hline $37 \mathrm{OR}$ & January 23, 2014 & 4.30 & $15.0 \pm 8.8$ & 3 & 406 & 298 & - & 3-chase \\
\hline
\end{tabular}

Deployment dates, lengths and the number of foraging trips are listed per individual. Dive depth is mean $(\bar{X}) \pm$ standard deviation (SD). Listed mass obtained during recovery capture. Target prey: 1 Antarctic fur seal adult, 2 Antarctic fur seal pup, 3 notothen fish, 4 penguin. Carcass indicates the consumption of a scavenged/cached carcass within an individual's video record. Seal $394 \mathrm{Y}$ made no capture attempts within the video record. Hunting tactics that were successful $>50 \%$ of the time are highlighted in italics. 
epoxy. All deployments and recoveries were conducted on chemically immobilized seals.

During the 2013 and 2014 seasons, these seven study animals were each captured twice $(N=14)$ using a midazolam-butorphanol sedation protocol [71]. The duration of these captures ranged between 37 and $91 \mathrm{~min}$. All pharmaceuticals and doses fell within the reported safe ranges [71]. Prior to release, each animal was weighed in a sling using a tripod, hand winch, and a digital scale (MSI-7300 Dyna-Link 2, capacity 1,000 $\pm 0.5 \mathrm{~kg}$ ).

All target animals were successfully sedated. Each animal's recovery was visually monitored until it recovered to a mobile state. The average recovery time was $7.17 \pm 6.20$ (range 1-19) min. No tachycardia or respiratory distress was observed during captures. All animals in this study were resighted at least once within 2 weeks of capture, in a healthy state. No reduced motor function or infection was observed.

\section{Data analysis}

TDR data were downloaded using software provided by the manufacturer [Wildlife Computers (WC): Mk9 Host v1.09, Mk10 Host v1.26; National Geographic Remote Imaging: Crittercam GUI; Star Oddi: SeaStar v5.24]. All dive records were zero-offset corrected (ZOC) for pressure transducer calibration drift [WC Instrument Helper, ZOC method = "automatic", or (diveMove [72]) ZOC method = "visual"]. Utilizing time-date stamps and instrument 'dry' periods [salt water switch was dry continuously for $>2.4 \mathrm{~h}(\mathrm{~h})$ ], dive and foraging variables were calculated using a customized Excel form including: number and length of foraging trips, the number and length of haul-out periods, number of dives/foraging trip, and mean max depth/per foraging trip. The haulout periods during which instruments were deployed or recovered were excluded from analysis because total lengths were unknown.

High-definition CRITTERCAM video data were reviewed using Quicktime Player v.7.7.4. Using the definitions listed in Additional file 2, three independent observers each scored $50.3 \mathrm{~h}$ of video footage by time of day, habitat type (shallow, coastal, deep), behavior [hauled out, resting, traveling, searching, waiting, breath stop, non-feeding event (inter- or intraspecific)], feeding event [target prey, pursuit tactic (Table 2) (ambush, stalk, chase, flush, incidental, handling, processing)], capture success, and consumption success. A foraging attempt was any detectable movement in pursuit of an identifiable prey item, while a non-feeding event described the presence of any animal that was not pursued. The definitions of large carnivore hunting tactics vary across studies based on the terrain, target prey, and hunter morphology [23, 50, 73-78]. The descriptions in Table 2 attempt to distill the fundamental aspects of these terms common across carnivore systems. Observations were entered into a time-linked database. Fish were identified to species by an Antarctic fish specialist (Jones Personal communication $^{\mathrm{b}}$ ) and confirmed with identification keys [79]. Leopard seals observed during social encounters were identified, when possible, by comparing video segments to US-AMLR tag and photo ID catalogs; identifications were verified by three independent observers.

Fastloc GPS data were downloaded and surface position locations were calculated using manufacturer software [DAP Processor (WC); Sirtrack and Pathtrack archival GPS Ver. 1.11]. Solved positions based on fewer than six satellites [59], residual error $>15.0$ (WC), or with a Pathtrack LocSolve accuracy indicator $<30$ were removed. All subsequent data analysis was conducted using $R$ [80]; all relevant $R$ packages are listed in brackets with citations. Remaining GPS positions were passed through a filter to remove positions requiring travel speeds $>4 \mathrm{~m} / \mathrm{s}$ [argosfilter [81]].

To link video-observed behaviors with foraging habitat, post-filter GPS data were further analyzed, and animations and behavior maps were created [tlocoh [82]]. Each GPS data set per individual leopard seal was reviewed to ensure even time-sampling interval of locations; all temporally concentrated location 'burst' segments were removed to reduce bias [83]. Time Local Convex Hulls (T-LoCoH) are essentially minimum convex polygons created for each GPS location based on a given number of nearest neighbor points which are local in space and time. Nearest neighbors were selected using

Table 2 Hunting tactic definitions

\begin{tabular}{ll}
\hline Hunting tactic & Definition \\
\hline Ambush & Moving into an advantageous position and using surprise to capture prey with a rush or quick grasp \\
Stalk & Actively tracking, and moving slowly to close the distance to prey while avoiding detection, typically ending in a rush to capture \\
Chase & Any accelerated swim or maneuver to pursue prey; chases tend to be longer than the 'burst rushes' of ambush or stalk techniques \\
Flush & Using a body part, vocalization, or other means to move prey away from shelter \\
Incidental & An interaction with a potential prey that was not precipitated by any notable pursuit effort
\end{tabular}

Definitions based on a literature review of carnivore hunting tactics. 
the adaptive ('a') method [84]. Each hull (e.g., Additional file 3) has several characteristics by which an individual animal's movement can be described: (1) elongation (eccentricity, 'ecc') which is a basic measure of directionality (indicated by the red oval in Additional file 3). Sorting the hulls by ecc produces a color-coded behavior map of movement, or elongation distribution. The color scale ranges from red (likely transit behavior) to light blue (little or no directionality) (2) revisitation (number of separate visits to a given hull, 'nsv') which provides a metric for how often an animal revisited a given area, and (3) duration (mean length of visit, 'mnlv') which indicates how long an individual spent in a given hull per visit [56]. Separate visits were defined by an inter-visit gap period of $\geq 3 \mathrm{~h}$.

Plots of position color coded by foraging trip, elongation distributions, and position maps color coded by duration and revisitation rates were created for each animal [83]. Duplicate points (two GPS positions in the exact same location) were offset by $1 \mathrm{~m}$. All T-LoCoH map locations were plotted in a Universal Transverse Mercator (UTM) zone 20 projection. The $x$-axis (easting) and $y$-axis (northing) were plotted in meters.

Area maps were created using Antarctic coastline data from the SCAR Antarctic Digital Database [ggplot2 [85]]. All values are listed as mean $(\bar{X}) \pm$ standard deviation (SD) unless otherwise indicated. Prey processing times per individual leopard seal were compared using Welch's two-sample $t$ tests, with a level of significance of $p \leq 0.05$.

\section{Results}

The average deployment length was $4.80 \pm 2.45$ (range 0.86-9.12) days (d), which cumulatively covered 16 leopard seal foraging trips (Table 1). Thirty-nine prey capture attempts and 11 leopard seal social encounters were scored from $50.3 \mathrm{~h}$ of video data. We obtained 3,833 post-filter GPS positions (Additional file 1), accurate to within $70 \mathrm{~m}$ [59]. The mean dive depth was $14.84 \pm 8.98 \mathrm{~m}$ (Table 1 ) and the mean maximum depth was $62.0 \pm 15.3 \mathrm{~m}$ (range $47-84 \mathrm{~m}$ ). On average, leopard seals spent $58.2 \pm 22.6$ (range $40.3-72.2$ ) \% of deployment time hauled out on land. Despite variance between individual seals in the percent time they spent in each behavioral state (Additional file 4), leopard seals consistently spent most of their in-water time searching for prey $(50.4 \pm 26.9 \%)$ or immobile and resting $(23.2 \pm 21.1 \%$, Fig. 2). Feeding behavior was focused on four prey items: Antarctic fur seals, Antarctic fur seal pups, demersal notothen fishes, and Pygoscelid penguins (Fig. 3). The key targets were Antarctic fur seal pups, successfully captured in $76.5 \%$ of attempts, and notothen fishes, captured in $64.3 \%$ of attempts.

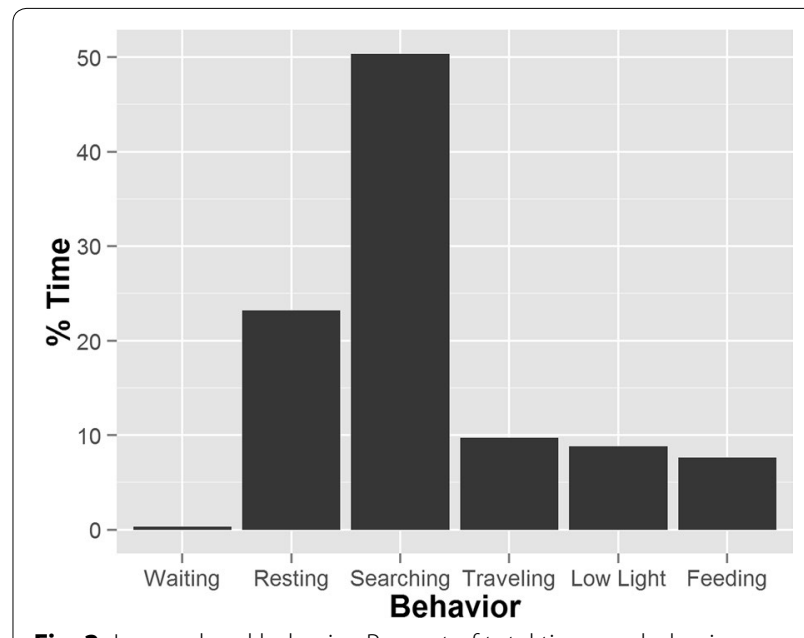

Fig. 2 Leopard seal behavior. Percent of total time per behavior based on scored CRITTERCAM video. "Low Light" refers to any video segment that was too dark, or obscured to reliably identify behavior.

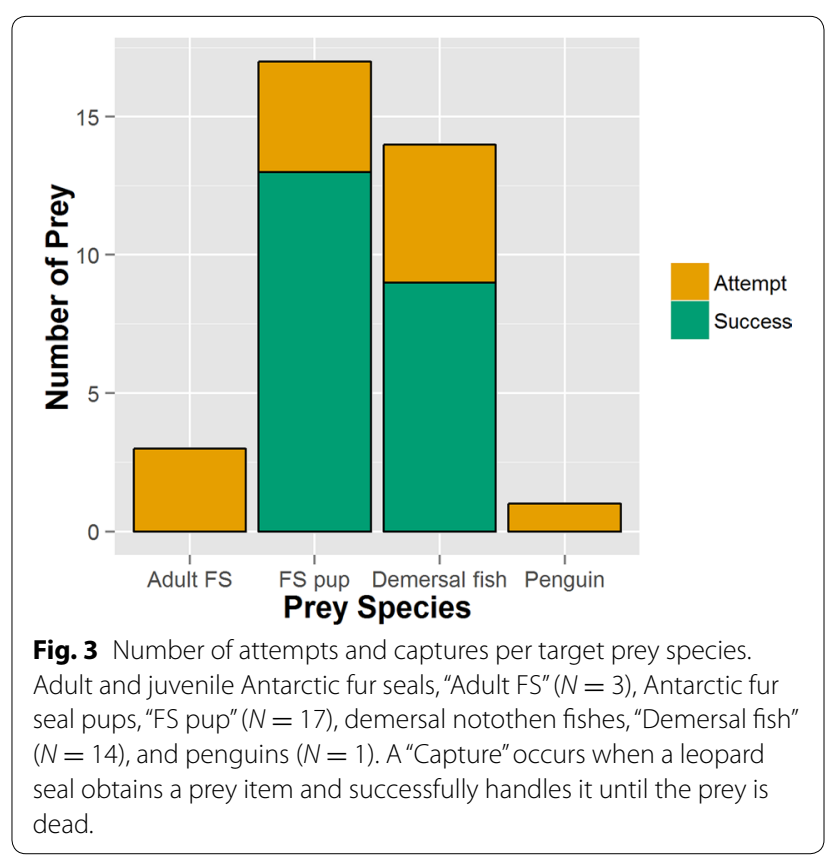

\section{Hunting tactics}

At Cape Shirreff, five of the seven leopard seals targeted Antarctic fur seals (Table 1). Adult female or juvenile male fur seals $(N=3)$ were pursued using a chase tactic, and none were captured. Four leopard seals attempted to capture at least one fur seal pup, but the high capture success rates were driven by three individuals (422Y, $406 \mathrm{Y}$ and 397G) which succeeded in 13 of 14 attempts; all of which used an intertidal ambush technique (Additional file 5). The other three leopard seals either made no fur seal pup attempt or were unsuccessful using a coursing/chase tactic (Fig. 4a). 
Four of the seven leopard seals attempted to catch a notothen fish. Fish hunting focused on three groups: unidentified demersal notothen fish $(N=5)$, humped rockcod (Gobionotothen gibberifrons) $(N=6)$, and black rockcod (Notothenia coriiceps) $(N=3)$. As with fur seal pup tactics, the overall capture success rates were driven by a subset of individuals. One leopard seal (401Y) employed either flush or stalk techniques and was $88.9 \%$ successful, while the other three individuals used chase tactics and were 20\% successful (Fig. 4b). In addition, $401 Y$ utilized prey-specific tactics. For all humped rockcod, seal 401Y inverted its body head-down and flushed the fish from rock cover or sponge beds with its snout (Additional file 6). Black rockcod were observed swimming approximately $2-3 \mathrm{~m}$ above the sea floor. The seal approached these fish from behind and below slowly and then abruptly struck when it was about $1 \mathrm{~m}$ away. Both fish species were taken to the surface to be processed. However, the humped rockcod were eaten whole, while the heads were removed from black rockcod, perhaps to reduce irritation from the black rockcod's prominent opercular spines [79].

\section{Foraging specialization}

For direct comparison of habitat use and foraging behavior, temporally overlapping deployments were conducted on two leopard seals (401Y and 397G) which hauled out regularly on the same beach. Leopard seal 401Y targeted only demersal fish and adult fur seals, while $397 \mathrm{G}$ targeted only fur seal pups, and these prey differences corresponded to distinct habitat use. While they both used the area around Cape Shirreff, 401Y was distinctly offshore (Fig. 5a), and 397G followed the coastline closely (Fig. 5b). Seal 401Y had high revisitation rates to three areas (Additional file 7) revealed by video data to be fishing grounds. The elongation distribution maps show that $401 \mathrm{Y}$ had low directionality within fishing areas but transited directly between them (Fig. 5c). Seal 397G transited between fur seal breeding beaches and had several rapid transits offshore to process kills (Fig. 5d). High revisitation rates seem to correspond to searching effort, which for $397 \mathrm{G}$ focused on fur seal breeding beaches (Additional file 8). Seal 397G searched along all fur seal beaches (purple color, Fig. 6), but ambush hunting behavior, mostly around the two largest breeding beaches (Fig. 1), increased her duration per hull (green color, Fig. 6).

\section{Kleptoparasitism}

One of the seven Cape Shirreff CRITTERCAM records (397G) covered 3 foraging days and contained ten successful Antarctic fur seal pup captures, six of which were stolen by at least three other adult female leopard seals. In addition, 397G attempted to steal a pup but was unsuccessful. Two of the kleptoparasitic females were identified from our study population by photo ID, both of which were longer (standard length) and heavier than 397G. These interactions are clearly aggressive (Additional file 9). Each consisted of a surprise attack, while $397 \mathrm{G}$ was beginning to process captured, dead pups followed by $19.5 \pm 5.2 \mathrm{~s}$ (s) of open-mouthed head strikes. While $100 \%(N=7)$ of leopard seal social interactions were agonistic when one had a captured pup, $0 \%(N=4)$ were agonistic when neither had a pup. All interactions were between two individuals, and when mass was known for both, the smaller leopard seal was never successful at defending captured prey.
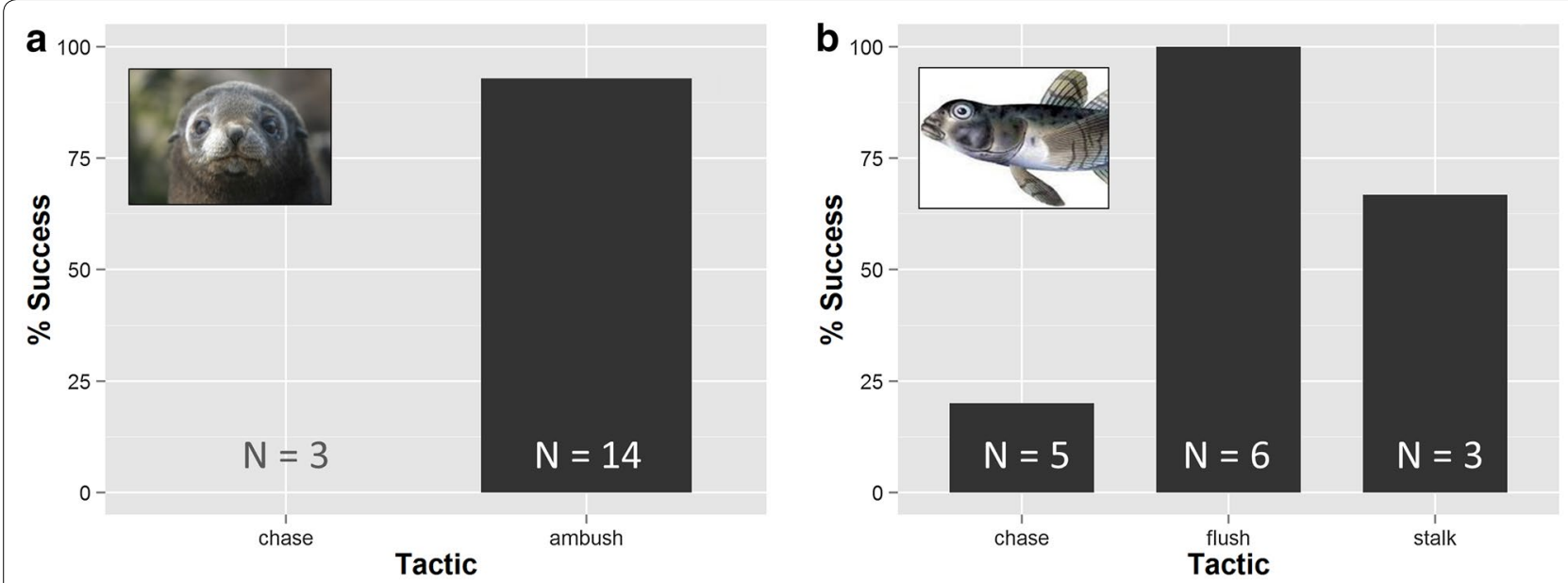

Fig. 4 Prey capture success rates by hunting tactic. Target prey were: a Antarctic fur seal pups and $\mathbf{b}$ notothen fishes. 


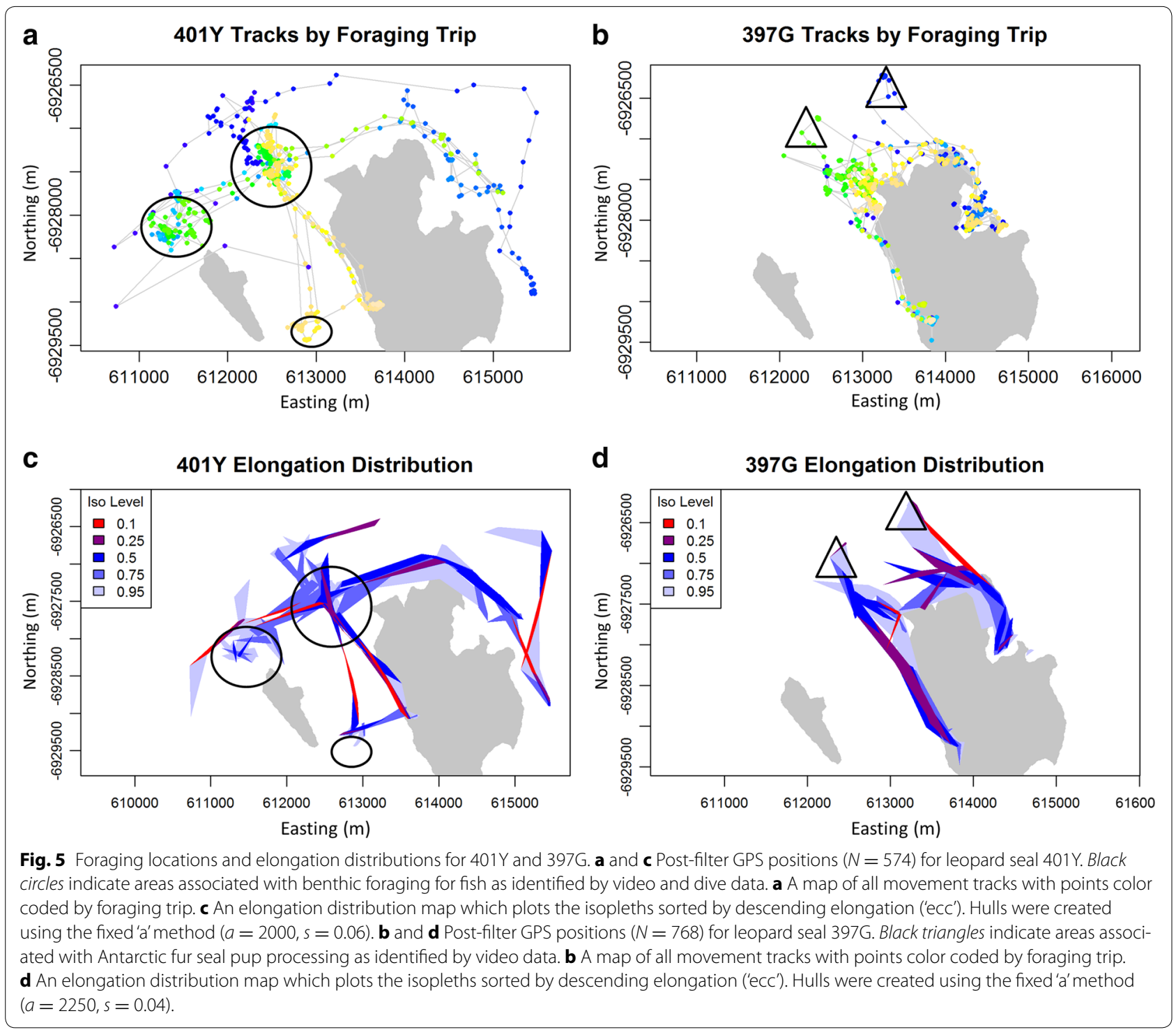

\section{Scavenging/food caching}

Three leopard seals at Cape Shirreff were observed on CRITTERCAM video to discover and consume carcasses (one penguin, and two fur seal) on the sea floor in $18-32 \mathrm{~m}$ of water. These scavenged prey items represent $22.2 \%$ of all fur seal pups $(N=9)$ and $100 \%$ of all penguins $(N=1)$ consumed in the study (Fig. 7$)$.

\section{Discussion}

Large carnivore hunting tactics include one or a combination of sit-and-wait, stalk, flush, ambush, or chase/ coursing techniques $[50,74,76,77]$, which are selected based on prey movement, size, and vulnerabilities [23, 48, 73]. Studying the tactics used by carnivores has provided insight into the impact pathways between predators and their ecosystem [23], the influence of environmental factors and terrain $[78,86]$, and the importance of inter- and intraspecific competition [23, 51, 87, 88]. Although the bulk of this field has been focused on terrestrial systems, the adaptations of marine carnivores should facilitate similar environmental and energetic evolutionary drivers of hunting behavior [89].

\section{Hunting tactics}

The majority of previous reports on leopard seal hunting tactics were recorded at penguin colonies, and described two approaches: a sit-and-wait technique, used if there was available cover and a reliable procession of penguins $[20,90]$, or an ambush in the water or ice edge [7, 19, 21]. Chase techniques were rarely reported and were 


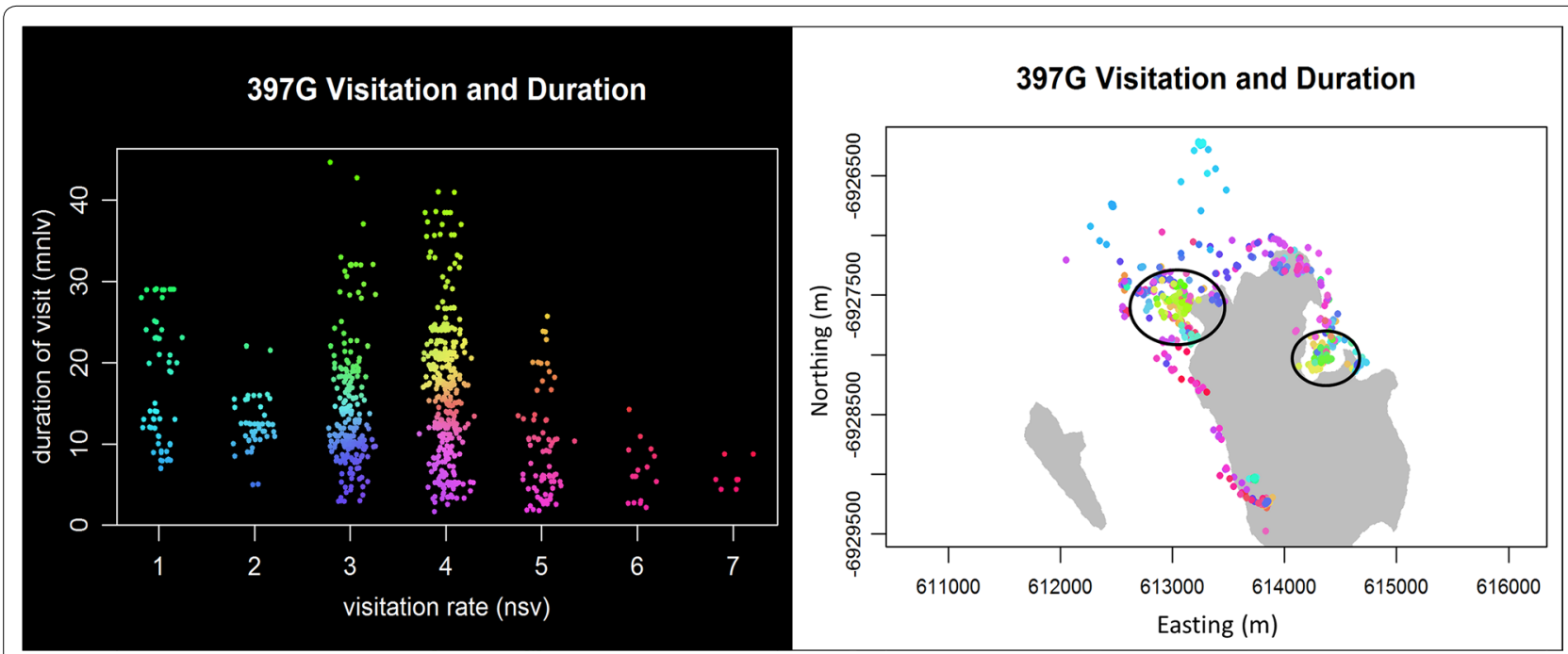

Fig. 6 Re-visitation and duration behavior plots for 397G. Hulls were created using the fixed 'a' method ( $a=2250, s=0.04)$. Left pane-a scatterplot where each point represents a hull color coded by location duration ("mnlv") and re-visitation ("nsv") $(N=768)$. Points were each jiggled (by 0.1 on $x$-axis, by 0.05 on $y$-axis) to better see point density. Right pane-animal location hulls colored based on their position in mnlv-nsv space. Active ambush hunting behavior areas are denoted by black ovals.

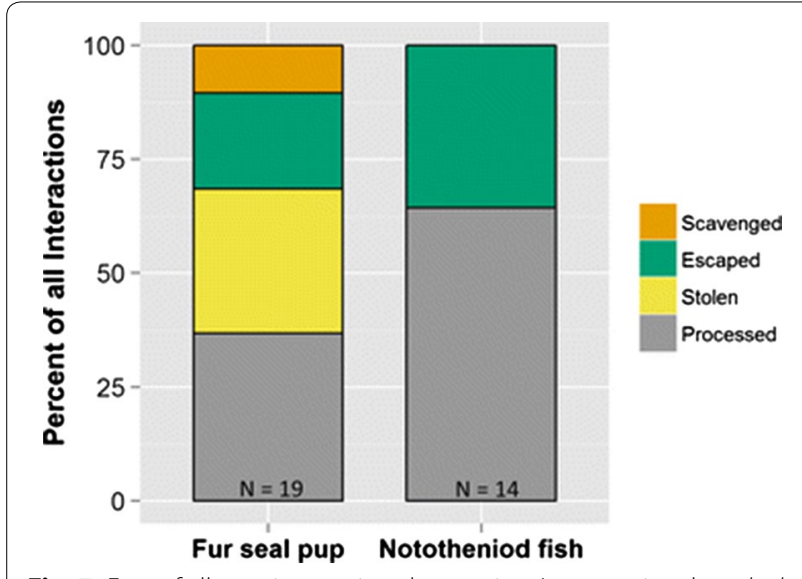

Fig. 7 Fate of all prey interactions by species. A proportional stacked plot indicating the outcomes for each leopard seal encounter with Antarctic fur seal pups and notothen fishes.

unsuccessful [21]. One study of hunting tactics on Antarctic fur seals indicated that a small number of leopard seals using an ambush technique in intertidal areas had the biggest impact; while chase techniques were seen, they were rarely successful [17].

At Cape Shirreff, leopard seals used both chase and ambush tactics when hunting fur seals. As with previous studies, successful hunting was driven by a subset of individuals using an ambush tactic. Chase tactics were used opportunistically by leopard seals, though success rates were low (Table 1). The specialized intertidal ambush technique was likely developed because small mesopredators can out-maneuver leopard seals in open water, but in shallow coastal areas leopard seals can use restricted space, cover, and surprise to their advantage [91].

To our knowledge, foraging tactics by free-ranging leopard seals on fish have not previously been reported. A video-based study of Weddell seal foraging behavior identified hunting tactics on two groups of notothen fishes; large benthic Antarctic cod were stalked, while smaller ice-associated fishes were flushed from ice cracks with air bubbles [50]. The Cape Shirreff population of leopard seals all spent most of their searching effort on the benthos near shore, yet most animals had no or low success capturing demersal fish. However, one individual (401Y), utilized prey-specific stalk and flush techniques to great effect. These initial results of predation on fur seal pups and notothen fish suggest that individual-based hunting specialization is important for this population of leopard seals.

\section{Foraging specialization}

Reports based on the diet and morphology of leopard seals describe a generalist apex predator that will readily adjust its foraging effort toward the most available prey resource across a broad spectrum of the Antarctic food web $[4,15,92]$. Their slender body form and large fore flippers provide speed and maneuverability [93]. Leopard seals have the longest jaws of any seal [94]. That massive gape contains a combination of carnivorous recurved 
canines and interlocking tricuspid postcanines [92, 93] that can subdue large-bodied prey, or sieve krill and fish as needed [95]. Despite these general traits, whether individual leopard seals readily switch prey across trophic levels or develop specialized foraging strategies is not known.

Many marine predators develop specialized hunting tactics [96, 97], and intraspecific competition can drive the development of individual-based specialized foraging strategies in marine carnivores [98-100]. Indeed, high leopard seal densities seem to be coincident with preyspecific hunting tactics at Cape Shirreff. In addition, two study animals (401Y and 397G) with practically identical foraging options employed distinct hunting tactics on different prey in separate areas around Cape Shirreff. Although sample sizes remain small, these prey-specific hunting tactics and distinctive movement patterns, along with previous observations $[17,21]$, suggest that leopard seals concentrated at mesopredator breeding colonies employ specialized foraging techniques.

\section{Kleptoparasitism}

Although generally solitary, observations of two or more free-ranging leopard seals interacting have been reported [17 and references therein]. Some of these interactions were attributed to play or cooperative hunting; however, other interactions involving a prey item obtained by one leopard seal and transferred to another were less clear [17]. These and other shore-based reports, which indicated that up to $14.2 \%$ of all fur seal pup captures at Cape Shirreff may have been stolen [18], could not be confirmed without underwater observations [17].

Kleptoparasitism is a potentially important competition pathway realized when a parasite steals food from a host [101]. Predatory carnivores have high energetic costs due to hunting; therefore, kleptoparasitism can affect individual and population viability [102-104]. Although kleptoparasitism is common across animal taxa, it has rarely been described for mammals in marine systems [105] with notable exceptions $[51,106]$. Animalborne video data from Cape Shirreff confirm that at least some prey exchanges between adult leopard seals are aggressive and kleptoparasitic (Additional file 9).

In systems where kleptoparasitism is common, hosts develop strategies to build resilience to the loss of energy $[101,105,107]$. Therefore, if kleptoparasitism is persistent for leopard seals at Cape Shirreff, hosts should utilize the most efficient hunting tactics [88], have higher prey capture rates [108], and process their prey more quickly than non-hosts [104]. And, indeed, 397G utilized the most successful tactic in the study (ambush), had the highest pup capture rate per foraging time [2.43 pups/h vs. $1.78 \mathrm{pups} / \mathrm{h}(422 \mathrm{Y})$ or $0.18 \mathrm{pups} / \mathrm{h}(406 \mathrm{Y})]$, and had the lowest pup processing times $(\bar{X}=10.38 \pm 2.03 \mathrm{~min}$, $t=-3.2, p \leq 0.01)$. In addition, 397G moved away from the pup capture location to process prey and, ostensibly, to avoid kleptoparasites (Fig. 5b), while other, larger animals (e.g., 422Y, 406Y) did not. Although the sample size is limited, these results suggest that kleptoparasitism is a substantial competitive pathway among adult leopard seals.

\section{Scavenging/food caching}

Leopard seals foraging at mesopredator colonies have been reported to kill penguins (Ponganis personal communication ${ }^{c}$, Lescroël personal communication, ${ }^{\mathrm{d}}$ [20]) or fur seal pups (US-AMLR unpublished observations) in excess of what they immediately processed and ate. There is a spectrum in carnivore behavior describing a predator killing prey in excess of its immediate consumption needs. One end of that spectrum is "surplus killing" when a carnivore kills one or more prey, but never consumes them [109]. On the other end is "food caching" which, for carnivores, describes a satiated predator that continues to kill prey and either store or defend it until it can be consumed later [110]. Even though no energy is gained, there are advantages to surplus killing, including hunting practice for immature animals [109] or in the organization of social structure [73]. Almost all examples of surplus killing involve environmental or pathological factors (e.g., severe weather, disease) that inhibit prey from their natural predator defense mechanisms [109]. In all known reports of leopard seals killing excess prey, there are no such inhibitions to predator defense. Further, the list of potential advantages for surplus killing does not extend to solitary adult leopard seals, implying that reports of excess prey killing likely lead to food caching.

Food caching is a behavioral hedge against competition for limited resources [111] and is associated with variable environments and unpredictable food availability [112]. Although a taxonomically broad spectrum of terrestrial birds and mammals demonstrates food caching [110], it has only been reported for two marine mammals to date. Transient killer whales (Orcinus orca) in the northeastern Pacific were reported to abandon gray whale (Eschrichtius robustus) kills but return to feed on the submerged carcasses [113]. And, Weddell seals (Leptonychotes weddellii) in the Ross Sea region have been observed to cache fish in breathing holes [114, 115].

A leopard seal at Cape Washington was observed patrolling within $10 \mathrm{~m}$ of a previously killed, partially stripped emperor penguin in an ice lead. That seal made aggressive movements and vocalizations when researchers approached the penguin carcass, and it eventually consumed the carcass ('Ponganis personal communication, Additional file 10). Three of the seven leopard seals 
at Cape Shirreff consumed mesopredator carcasses in this study. Because there are no other marine apex predators at Cape Shirreff, we can assume that all three scavenged carcasses resulted from previous leopard seal kills. Furthermore, due to rapid processing by shallow water amphipods (Orchomenella sp., US-AMLR unpublished observations), the carcasses were no more than a few days old.

A second continuum of behavior exists within the context of carnivore scavenging with "sloppy feeding" at one end and, again, "food caching" on the other. While both refer to a situation in which a predator scavenges a carcass, sloppy feeding applies when the carcass was present through inefficient prey processing by the original predator [116], and food caching applies when the prey was killed and stored with the intent of future recovery [117]. The food caching strategy becomes advantageous when an individual can recover its kills, or another's kills, at a rate consummate with its predatory effort [118]. Fur seal pup carcass processing by leopard seals is similar to penguin processing $[20,119]$. The leopard seal whips the carcass violently back and forth (Additional file 9) until the skin has been peeled back to expose the viscera and body muscle, which the leopard seal consumes. Three lines of evidence suggest that scavenged carcasses at Cape Shirreff were cached: (1) mesopredator carcass processing has been observed frequently and does not match the sloppy feeding description (US-AMLR unpublished observations) (2) any kill remains left at the surface are immediately consumed by predatory birds including brown skuas (Stercorarius antarcticus), giant petrels (Macronectes giganteus), and Wilson's storm petrels (Oceanites oceanicus). So for a carcass to survive for later consumption, we suspect that it must be deposited purposefully below its buoyancy composition depth, and (3) the adult leopard seal at Cape Washington was engaged in cache defense, and when one member of a species employs caching behavior, generally all do [118].

Irrespective of its label, facultative scavenging of carrion is both present in the behavior of leopard seals at Cape Shirreff and ecologically important. Scavenging is a biologically widespread behavior [120] that can structure communities and stabilize food webs [116]. At Cape Shirreff, scavenging was present in both field seasons. In addition, leopard seals spent $80.8 \%$ of their searching effort scouring the benthos despite a fish capture attempt rate $(0.56 / \mathrm{h})$ more than an order of magnitude lower than reports for other phocids $(9.3 / \mathrm{h},[48])$. This suggests that benthic-oriented searching may not be limited to fish hunting but may also focus on carrion which can provide high-quality food at low acquisition cost [116]. Due to its potential importance, we suggest that future predator impact models of Antarctic coastal ecosystems include a scavenging/caching impact pathway.

\section{Conclusions}

Leopard seals are probably affecting Antarctic coastal ecosystems through both direct and indirect pathways, several of which have not been studied or discussed to date. Mesopredator breeding colonies, in particular, appear to draw high densities of adult leopard seals that facilitate social interactions $[8,17,93,121]$. Social encounters at Cape Shirreff were often aggressive, indicating the influence of intraspecific interference competition. No evidence of cooperative hunting was found. Video and movement data suggest that leopard seals individually employ specialized, prey-specific hunting tactics including ambush tactics on Antarctic fur seal pups and flush and stalking tactics on notothen fishes.

Surprisingly, demersal fishes are a key prey item for leopard seals at Cape Shirreff, which puts them in direct competition with both Gentoo penguins and blue-eyed Antarctic shags [Phalacrocorax (atriceps) bransfielden$s i s$ that forage locally to provision their chicks during January and February. We report the first observations of predation attempts by leopard seals on non-pup fur seals in the WAP. These attacks suggest that predatorinduced stress effects on fur seal physiology and behavior are likely [11]. The most immediate indirect impacts to mesopredator populations, are likely driven by kleptoparasitism which can increase predation rates [108] and scavenging/caching which is an understudied but ecologically crucial energy pathway [116].

While these observations are preliminary, the regular occurrence of such novel behaviors within a relatively small sample size indicates that they are not unusual. Our expanded understanding of the importance of intraspecific competition and the indirect effects of leopard seals on Antarctic coastal ecosystems would not have been possible, and often could not have been anticipated, without the use of animal-borne video and Fastloc GPS. Given the potential magnitude of top-down forcing by leopard seals, we suggest expanding current studies to integrate diet and foraging ecology to verify these preliminary results and expand baseline data for future ecosystem models.

\section{Endnotes}

${ }^{a}$ United States Antarctic Marine Living Resources Program (US-AMLR) is administered by the NOAA Fisheries Antarctic Ecosystem Research Division (AERD), SWFSC La Jolla, CA, USA.

bones, C. D. Personal Communication. Dr. Christopher Jones provided assistance in identifying two species 
of notothen fish. AERD, SWFSC, La Jolla, CA 92037. November, 2014.

'Ponganis, P. Personal Communication. Dr. Paul Ponganis and his field crew at Cape Washington 2011 (B. McDonald, M. Tift, G. Marshall and M. Fowler) provided field observations, photos, and video of a probable leopard seal caching event. The video was supported by NSF Grant 0944220 to P. Ponganis. MMPA Permit 15261. Scripps Institution of Oceanography, UCSD, La Jolla, CA 92037. August, 2014.

${ }^{\mathrm{d}}$ Lescroël, A. Personal Communication. Dr. Amélie Lescroël shared observations of leopard seal predation on Adélie penguins at Cape Crozier during the Fifth International Bio-logging Conference, Strasbourg France. September, 2014.

\section{Additional files}

Additional file 1: Table of deployment and programming details for CRITTERCAM and GPS instruments.

Additional file 2: Table of variable and category descriptions used in scoring CRITTERCAM video. Categories and variables were entered into the database in the descending order presented in the table.

Additional file 3: An example time local convex hull. Randomly selected from the GPS data set of 401Y.

Additional file 4: Percent time per behavioral state by individual. By seal identification: (a) 406Y (b) 394Y (c) 422Y (d) 397G (e) 16OR (f) 401Y (g) 37OR.

Additional file 5: Video of the leopard seal ambush tactic. CRITTERCAM video clip of leopard seal $422 \mathrm{Y}$ ambushing an Antarctic fur seal pup in an intertidal area at Cape Shirreff.

Additional file 6: Video of the leopard seal flush tactic. CRITTERCAM video clip of leopard seal $401 Y$ flushing a humped rockcod (Gobionotothen gibberifrons) from a sponge bed.

Additional file 7: Animation of leopard seal 401Y GPS data set. The gray polygon represents Cape Shirreff, Livingston Island, the red dot is the emphasized or "current" position, and light gray dots represent the rest of the GPS data set for $401 Y$

Additional file 8: Animation of leopard seal 3976 GPS data set. The gray polygon represents Cape Shirreff, Livingston Island, the red dot is the emphasized or "current" position, and light gray dots represent the rest of the GPS data set for 397G.

Additional file 9: Video of a kleptoparasitic event. CRITTERCAM video clip of leopard seal 397G having a fur seal pup stolen by another leopard seal.

Additional file 10: Photo of a cached emperor penguin at Cape Washington. The feet of this dead, partially stripped emperor penguin carcass are visible in an ice lead about 1.5 meters from open water. Just off shore a female leopard seal is patrolling. Photo credit: M. Fowler.

\section{Authors' contributions}

DJK, MEG, GJM and KA conducted the fieldwork to collect video and movement data. GJM and KA provided training, technical support, and contributed to the sampling design for the CRITTERCAM instruments. DJK designed the study, supervised animal captures, conducted data analysis, and drafted the manuscript. All authors read and approved the final manuscript.

\section{Author details}

Antarctic Ecosystem Research Division, NOAA-NMFS-SWFSC, 8901 La Jolla Shores Drive, La Jolla, CA 92037, USA. ${ }^{2}$ Scripps Institution of Oceanography, University of California San Diego, Mail Code 0208, 9500 Gilman Drive, La Jolla, CA 92037, USA. ${ }^{3}$ National Geographic Society, Remote Imaging Group, 1145 17th Street NW, Washington, DC 20036, USA.

\section{Acknowledgements}

This paper was greatly improved by suggestions and comments by L. Ballance, P. Dayton, J. Hinke and two anonymous reviewers. We are grateful to K. Pietrzak, M. Mudge, J. Wright, N. Cook, M. Zimmerman, M. Goh, T. Joyce, N. Pussini, D. Vejar and J. Hinke for their assistance in the field. We thank L. Rodriguez, S. Pawlak, N. Lyon and K. Searles for scoring video footage. The financial, infrastructure and logistical support of the US-AMLR Program has made this work possible, and George Watters, its Director, is thanked enthusiastically. Funding for instruments and travel was provided by the National Geographic Society (NGS)/Waitt Grant\# W256-12, and a Mary Maude Vestal B. Houghes Pay-It-Forward travel grant. Intra-Antarctic transportation was kindly provided by Lindblad/NGS Expeditions, and logistical support by NGS Remote Imaging Leopard seal interactions and captures were conducted in accordance with Marine Mammal Protection Act Permit No. 16472-02 granted by the Office of Protected Resources, National Marine Fisheries Service, the Antarctic Conservation Act Permit No. 2012-005, and the NMFS-SWFSC Institutional Animal Care and Use Committee Permit No. SWPI2011-02.

\section{Compliance with ethical guidelines}

\section{Competing interests}

The authors declare that they have no competing interests.

Received: 14 January 2015 Accepted: 4 May 2015

Published online: 06 August 2015

\section{References}

1. Estes J, Tinker M, Williams T, Doak D (1998) Killer whale predation on sea otters linking oceanic and nearshore ecosystems. Science 282:473-476

2. Williams T, Estes J, Doak D, Springer A (2004) Killer appetites: assessing the role of predators in ecological communities. Ecology 85:3373-3384

3. Estes JA, Terborgh J, Brashares JS, Power ME, Berger J, Bond WJ et al (2011) Trophic downgrading of planet earth. Science 333:301-306

4. Laws R (1984) Seals. In: Laws RM (ed) Antarctic ecology, vol II. Academic Press, Cambridge, pp 621-716

5. Boveng P, Hiruki L, Schwartz M, Bengtson J (1998) Population growth of Antarctic fur seals: limitation by a top predator, the leopard seal? Ecology 79:2863-2877

6. Schwarz LK, Goebel ME, Costa DP, Kilpatrick AM (2013) Top-down and bottom-up influences on demographic rates of Antarctic fur seals Arctocephalus gazella. J Anim Ecol 82:903-911

7. Kooyman GL, Croll D, Stone S, Smith S (1990) Emperor penguin colony at Cape Washington, Antarctica. Polar Record 26:103-108

8. Ainley DG, Ballard G, Karl BJ, Dugger KM (2005) Leopard seal predation rates at penguin colonies of different size. Antarct Sci 17:335-340

9. Ballard WB, Carbyn LN, Smith DW (2003) Wolf interactions with nonprey. In: Mech LD, Smith DW (eds) Wolves: behavior, ecology and conservation. The University of Chicago Press, Chicago, pp 259-271

10. Creel S, Christianson D, Liley S, Winnie JA (2007) Predation risk affects reproductive physiology and demography of Elk. Science 315:960

11. Creel S, Christianson D (2008) Relationships between direct predation and risk effects. Trends Ecol Evol 23:194-201

12. Wirsing AJ, Heithaus MR, Frid A, Dill LM (2008) Seascapes of fear: evaluating sublethal predator effects experienced and generated by marine mammals. Mar Mamm Sci 24:1-15

13. Walker T, Boyd I, McCafferty D, Taylor R, Reid K (1998) Seasonal occurrence and diet of leopard seals (Hydrurga leptonyx) at Bird Island, South Georgia. Antarct Sci 10:75-81 
14. Casaux R, Baroni A, Ramón A, Carlini A, Bertolin M, DiPrinzio C (2009) Diet of the leopard seal (Hydrurga leptonyx) at the Danco Coast, Antarctic Peninsula. Polar Biol 32:307-310

15. Siniff DB, Stone S (1985) The role of the leopard seal in the trophodynamics of the Antarctic marine ecosystem. In: Siegfried WR, Condy PR, Laws RM (eds) Antarctic nutrient cycles and food webs. Springer Verlag, Berlin, pp 555-560

16. Green K, Williams R (1986) Observations on food remains in faeces of elephant, leopard and crabeater seals. Polar Biol 6:43-45

17. Hiruki L, Schwartz M, Boveng P (1999) Hunting and social behaviour of leopard seals (Hydrurga leptonyx) at Seal Island, South Shetland Islands, Antarctica. J Zool 249:97-109

18. Vera C, Vargas R, Torres DN (2005) Estrategias depredatorias del la foca leopardo sobre cachorros de lobo fino Antarctico. Boletin Antarctico Chileno 24:12-17

19. Penney RL, Lowry G (1967) Leopard seal predation of adelie penguins. Ecology 48:878-882

20. Kooyman GL (1965) Leopard seals of Cape Crozier. Animals 6:58-63

21. Rogers T, Bryden MM (1995) Predation of Adélie penguins (Pygoscelis adeliae) by leopard seals (Hydrurga leptonyx) in Prydz Bay, Antarctica. Can J Zool 73:1001-1004

22. Muller-Schwarze D, Muller-Schwarze C (1975) Relations between leopard seals and Adélie penguins. Rapports et Proces-Verbaux des Reunions du Conseil Permanent International pour l'Exploration de la Mer 169:394-404

23. Bertram BCR (1979) Serengeti predators and their social systems. In: Sinclair ARE, Norton-Griffiths M (eds) Serengeti: dynamics of an ecosystem. The University of Chicago Press, Chicago, pp 221-248

24. Macdonald DW (1983) The ecology of carnivore social behaviour. Nature 301:379-384

25. Wilmers CC, Crabtree RL, Smith DW, Murphy KM, Getz WM (2003) Trophic facilitation by introduced top predators: grey wolf subsidies to scavengers in Yellowstone National Park. J Anim Ecol 72:909-916

26. Kruuk H (1975) Functional aspects of social hunting by carnivores. In: Baerends G, Beer C, Manning A (eds) Function and evolution in behaviour. Oxford University Press, Oxford, pp 119-141

27. Gittleman JL (1989) Carnivore group living: comparative trends. In: Gittleman JL (ed) Carnivore behavior, ecology, and evolution. Cornell University Press, Ithaca, NY, pp 183-207

28. Creel S, Creel NM (1995) Communal hunting and pack size in African wild dogs, Lycaon pictus. Anim Behav 50:1325-1339

29. Mech LD, Peterson R (2003) Wolf-prey relations. In: Mech LD, Boitani $L$ (eds) Wolves: behavior, ecology, and conservation: behavior, ecology, and conservation. University of Chicago Press, Chicago, pp $131-160$

30. Palomares F, Caro TM (1999) Interspecific killing among mammalian carnivores. Am Nat 153:492-508

31. Murphy KM, Felzien GS, Hornocker MG, Ruth TK (1998) Encounter competition between bears and cougars: some ecological implications. Ursus 10:55-60

32. Schoener TW (1983) Field experiments on interspecific competition. Am Nat 122:240-285

33. Townsend CR, Begon M, Harper JL (2008) Essentials of ecology. WileyBlackwell Publishing, Malden

34. Wilson EA (1905) On the whales, seals and birds of Ross Sea and South Victoria Land. In: Scott R (ed) The voyage of the 'discovery', vol II. Charles Scribner's Sons, New York, pp 469-494

35. Southwell C, Paxton CGM, Borchers D, Boveng P, Rogers T, de la Mare WK (2008) Uncommon or cryptic? Challenges in estimating leopard seal abundance by conventional but state-of-the-art methods. Deep Sea Res Part 1 55:519-531

36. Gilbert J, Erickson A (1977) Distribution and abundance of seals in the pack ice of the Pacific sector of the Southern Ocean. In: Llano A (ed) Adaptations within Antarctic ecosystems. Smithsonian Institution, Washington, DC, pp 703-740

37. Rogers TL, Bryden MM (1997) Density and haul-out behavior of leopard seals (Hydrurga leptonyx) in Prydz Bay, Antarctica. Mar Mamm Sci 13:293-302

38. Rogers TL, Hogg CJ, Irvine A (2005) Spatial movement of adult leopard seals (Hydrurga leptonyx) in Prydz Bay, Eastern Antarctica. Polar Biol 28:456-463
39. Bester MN, Ferguson JWH, Jonker FC (2002) Population densities of pack ice seals in the Lazarev Sea, Antarctica. Antarct Sci 14:123-127

40. Meredith MP, King JC (2005) Rapid climate change in the ocean west of the Antarctic Peninsula during the second half of the 20th century. Geophys Res Lett 32:L19604

41. Vaughan D, Marshall G, Connolley W, Parkinson C, Mulvaney R, Hodgson D et al (2003) Recent rapid regional climate warming on the Antarctic Peninsula. Clim Change 60:243-274

42. Vaughan D (2006) Recent trends in melting conditions on the Antarctic peninsula and their implications for ice-sheet mass balance and sea level. Arct Antarct Alp Res 38:147-152

43. Forcada J, Trathan PN, Boveng PL, Boyd IL, Burns JM, Costa DP et al (2012) Responses of Antarctic pack-ice seals to environmental change and increasing krill fishing. Biol Conserv 149:40-50

44. Marshall G (1990) A video-collar to study aquatic fauna: a view from the animal's back. In: Reed D (ed) Spirit of enterprise: the 1990 rolex awards. Rolex, Geneva, Switzerland, pp 57-59

45. Parrish FA, Marshall GJ, Littnan CL, Heithaus MR, Canja S, Becker B et al (2005) Foraging of juvenile monk seals at French Frigate Shoals, Hawaii. Mar Mamm Sci 21:93-107

46. Parrish FA, Craig MP, Ragen TJ, Marshall GJ, Buhleier BM (2000) Identifying diurnal foraging habitat of endangered Hawaiian monk seals using a seal-mounted video camera. Mar Mamm Sci 16:392-412

47. Parrish FA, Abernathy K, Marshall GJ, Buhleier BM (2002) Hawaiian monk seals (Monachus schauinslandi) foraging in deep-water coral beds. Mar Mamm Sci 18:244-258

48. Bowen W, Tully D, Boness D, Bulheier B, Marshall GJ (2002) Prey-dependent foraging tactics and prey profitability in a marine mammal. Mar Ecol Prog Ser 244:235-245

49. Heaslip SG, Bowen WD, Iverson SJ (2014) Testing predictions of optimal diving theory using animal-borne video from harbour seals (Phoca vitulina concolor). Can J Zool 92:309-318

50. Davis R, Fuiman L, Williams T, Collier S, Hagey W, Kanatous S et al (1999) Hunting behavior of a marine mammal beneath the Antarctic fast ice. Science 283:993

51. Parrish FA, Marshall GJ, Buhleier B, Antonelis GA (2008) Foraging interaction between monk seals and large predatory fish in the Northwestern Hawaiian Islands. Endanger Species Res 4:299

52. Worton BJ (1989) Kernel methods for estimating the utilization distribution in home-range studies. Ecology 70:164-168

53. Austin D, Bowen WD, McMillan Jl (2004) Intraspecific variation in movement patterns: modeling individual behaviour in a large marine predator. Oikos 105:15-30

54. McClintock BT, King R, Thomas L, Matthiopoulos J, McConnell BJ, Morales JM (2012) A general discrete-time modeling framework for animal movement using multistate random walks. Ecol Monogr 82:335-349

55. Freitas C, Kovacs K, Ims R, Fedak M, Lydersen C (2008) Ringed seal post-moulting movement tactics and habitat selection. Oecologia 155:193-204

56. Lyons A, Turner W, Getz W (2013) Home range plus: a space-time characterization of movement over real landscapes. Mov Ecol 1:1-14

57. Rutz C, Hays GC (2009) New frontiers in biologging science. Biol Lett 5:289-292

58. Costa DP, Robinson PW, Arnould JPY, Harrison A-L, Simmons SE, Hassrick JL et al (2010) Accuracy of ARGOS locations of Pinnipeds at-sea estimated using Fastloc GPS. PLoS One 5:e8677

59. Dujon AM, Lindstrom RT, Hays GC (2014) The accuracy of Fastloc-GPS locations and implications for animal tracking. Methods Ecol Evol 5:1162-1169

60. Tomkiewicz SM, Fuller MR, Kie JG, Bates KK (2010) Global positioning system and associated technologies in animal behaviour and ecological research. Philos Trans R Soc B Biol Sci 365:2163-2176

61. Kie JG, Matthiopoulos J, Fieberg J, Powell RA, Cagnacci F, Mitchell MS et al (2010) The home-range concept: are traditional estimators still relevant with modern telemetry technology? Philos Trans R Soc B Biol Sci 365:2221-2231

62. Getz WM, Wilmers CC (2004) A local nearest-neighbor convex-hull construction of home ranges and utilization distributions. Ecography 27:489-505

63. Dayton PK, Mordida BJ, Bacon F (1994) Polar marine communities. Am Zool 34:90-99 
64. Orsi AH, Whitworth T III, Nowlin WD Jr (1995) On the meridional extent and fronts of the Antarctic circumpolar current. Deep Sea Res Part I 42:641-673

65. Atkinson A, Siegel V, Pakhomov EA, Jessopp MJ, Loeb V (2009) A reappraisal of the total biomass and annual production of Antarctic krill. Deep Sea Res Part I 56:727-740

66. Agnew DJ (1997) Review-the CCAMLR ecosystem monitoring programme. Antarct Sci 9:235-242

67. Goebel ME, Pussini N, Buchheit R, Pietrzak KW, Krause DJ, Van Cise AM et al (2011) AMLR 2010/11 field season report. Chapter 8: Pinniped Research at Cape Shirreff, Livingston Island, Antarctica. US Department of Commerce, NOAA Technical Memorandum NMFS-SWFSC-524, pp 50-57

68. Rogers TL, Ciaglia MB, Klinck H, Southwell C (2013) Density can be misleading for low-density species: benefits of passive acoustic monitoring. PLoS One 8:e52542

69. Erickson AW, Hofman RJ (1974) Antarctic seals. Antarctic Map Folio Series. Folio 18:4-13

70. Marshall G, Bakhtiari M, Shepard M (2007) An advanced solid-state animal-borne video and environmental data-logging device ("Crittercam") for marine research. Mar Technol Soc J 41:31-38

71. Pussini N, Goebel ME (2015) A safter protocol for field immobilization of leopard seals (Hydrurga leptonyx). Mar Mamm Sci. doi:10.1111/ mms.12232

72. Luque SP (2007) Diving behaviour analysis in R. R News 7:8-14

73. Kruuk H (1972) The spotted hyena: a study of predation and social behavior. University of Chicago Press, Chicago

74. Schaller GB (1972) The Serengeti lion: a study of predator-prey relations. University of Chicago Press, Chicago

75. Taylor M (1989) Locomotor adaptations by carnivores. In: Gittleman J (ed) Carnivore behavior, ecology, and evolution. Cornell University Press, Ithaca, NY, pp 382-409

76. Van Orsdol KG (1984) Foraging behaviour and hunting success of lions in Queen Elizabeth National Park, Uganda. Afr J Ecol 22:79-99

77. Caro TM, Fitzgibbon CD (2009) Large carnivores and their prey: the quick and the dead. In: Crawley MJ (ed) Natural enemies: the population biology of predators, parasites and diseases. Blackwell Scientific Publications, Oxford, pp 115-142

78. Hilborn A, Pettorelli N, Orme CDL, Durant SM (2012) Stalk and chase: how hunt stages affect hunting success in Serengeti cheetah. Anim Behav 84:701-706

79. Gon O, Heemstra PC (eds) (1990) Fishes of the southern ocean, 1st edn. JLB Smith Institute of Ichthyology, Grahamstown

80. R-Core-Team (2014) R: a language and environment for statistical computing. R Foundation for Statistical Computing, Vienna, Austria

81. Freitas C (2012) argosfilter: Argos locations filter. R Foundation for Statistical Computing, Vienna, Austria

82. Lyons AJ, Getz WM (2014) T-LoCoH: time local convex hull homerange and time use analysis. R Foundation for Statistical Computing, Vienna, Austria

83. Lyons AJ (2014) T-LoCoH for R: tutorial and users guide, pp 2-53

84. Getz WM, Fortmann-Roe S, Cross PC, Lyons AJ, Ryan SJ, Wilmers CC (2007) LoCoH: nonparameteric kernel methods for constructing home ranges and utilization distributions. PLoS One 2:e207

85. Wickham H (2009) ggplot2: elegant graphics for data analysis. Springer, New York

86. Murray DL, Boutin S, O'Donoghue M, Nams VO (1995) Hunting behaviour of a sympatric felid and canid in relation to vegetative cover. Anim Behav 50:1203-1210

87. Stirling I (1974) Midsummer observations on the behavior of wild polar bears (Ursus maritimus). Can J Zool 52:1191-1198

88. Scantlebury DM, Mills MGL, Wilson RP, Wilson JW, Mills MEJ, Durant SM et al (2014) Flexible energetics of cheetah hunting strategies provide resistance against kleptoparasitism. Science 346:79-81

89. Estes JA (1989) Adaptations for aquatic living by carnivores. In: Gittleman JL (ed) Carnivore behavior, ecology, and evolution. Cornell University Press, Ithaca, NY, pp 242-282

90. Mader TR (1998) Temporal variation in leopard seal presence and predation near an antarctic penguin rookery. Masters Thesis Montana State University, Biology
91. DeLaca T, Lipps J, Zumwalt G (1975) Encounters with Leopard seals (Hydrurga leptonyx) along the Antarctic Peninsula. Antarct J Unit States 10:85-91

92. Rogers T (2009) The leopard seal, Hydrurga leptonyx. In: Perrin WF, Wursig B, Thewissen JGM (eds) Encyclopedia of marine mammals, 2nd edn. Academic Press, San Diego, pp 673-674

93. Kooyman GL (1981) Leopard seal (Hydrurga leptonyx Blainville, 1820). In: Ridgway S, Harrison R (eds) Handbook of marine mammals, vol 2. Academic Press, London, pp 261-272

94. Ray C (1966) Snooping on seals for science. Anim Kingd 69:66-75

95. Hocking D, Evans A, Fitzgerald EG (2013) Leopard seals (Hydrurga leptonyx) use suction and filter feeding when hunting small prey underwater. Polar Biol 36:211-222

96. Pitman RL, Durban JW (2012) Cooperative hunting behavior, prey selectivity and prey handling by pack ice killer whales (Orcinus orca), type B, in Antarctic Peninsula waters. Mar Mamm Sci 28:16-36

97. Pitman RL, Totterdell JA, Fearnbach H, Ballance LT, Durban JW, Kemps $H$ (2015) Whale killers: prevalence and ecological implications of killer whale predation on humpback whale calves off Western Australia. Mar Mamm Sci 31(2):629-657

98. Estes JA, Riedman ML, Staedler MM, Tinker MT, Lyon BE (2003) Individual variation in prey selection by sea otters: patterns, causes and implications. J Anim Ecol 72:144-155

99. Staniland IJ, Reid K, Boyd IL (2004) Comparing individual and spatial influences on foraging behaviour in Antarctic fur seals Arctocephalus gazella. Mar Ecol Prog Ser 275:263-274

100. Weise MJ, Harvey JT, Costa DP (2010) The role of body size in individual-based foraging strategies of a top marine predator. Ecology 91:1004-1015

101. Brockmann HJ, Barnard CJ (1979) Kleptoparasitism in birds. Anim Behav 27(Part 2):487-514

102. Creel S, Creel N (1996) Limitation of African wild dogs by competition with larger carnivores. Conserv Biol 10:526-538

103. Gorman ML, Mills MG, Raath JP, Speakman JR (1998) High hunting costs make African wild dogs vulnerable to kleptoparasitism by hyaenas. Nature 391:479-481

104. Krofel M, Kos I, Jerina K (2012) The noble cats and the big bad scavengers: effects of dominant scavengers on solitary predators. Behav Ecol Sociobiol 66:1297-1304

105. lyengar EV (2008) Kleptoparasitic interactions throughout the animal kingdom and a re-evaluation, based on participant mobility, of the conditions promoting the evolution of kleptoparasitism. Biol J Linn Soc 93:745-762

106. Riedman ML, Estes JA (1988) A review of the history, distribution and foraging ecology of sea otters. In: VanBlaricom GR, Estes JA (eds) The community ecology of sea otters, vol 65. Springer, Berlin, pp 4-21

107. Creel S, Spong G, Creel N (2001) Interspecific competition and the population biology of extinction-prone carnivores. In: Gittleman JL, Funk SM, Macdonald DW, Wayne RK (eds) Carnivore conservation. Cambridge University Press, London, pp 35-60

108. Krofel M, Kos I (2010) Modeling potential effects of brown bear kleptoparasitism on the predation rate of Eurasian lynx. Acta Biologica Slovenica 53:47-54

109. Kruuk H (1972) Surplus killing by carnivores. J Zool 166:233-244

110. Vander Wall SB (1990) Food hoarding in animals. University of Chicago Press, Chicago

111. Andersson M, Krebs J (1978) On the evolution of hoarding behaviour. Anim Behav 26(Part 3):707-711

112. Smith CC, Reichman OJ (1984) The evolution of food caching by birds and mammals. Annu Rev Ecol Syst 15:329-351

113. Barrett-Lennard LG, Matkin CO, Durban JW, Saulitis EL, Ellifrit D (2011) Predation on gray whales and prolonged feeding on submerged carcasses by transient killer whales at Unimak Island, Alaska. Mar Ecol Prog Ser 421:229-241

114. Kim SL, Conlan K, Malone DP, Lewis CV (2005) Possible food caching and defence in the Weddell seal: observations from McMurdo Sound, Antarctica. Antarct Sci 17:71-72

115. Ponganis PJ, Stockard TK (2007) Short note: the Antarctic toothfish: how common a prey for Weddell seals? Antarct Sci 19:441-442

116. Wilson EE, Wolkovich EM (2011) Scavenging: how carnivores and carrion structure communities. Trends Ecol Evol 26:129-135 
117. Macdonald DW (1976) Food caching by red foxes and some other carnivores. Zeitschrift für Tierpsychologie 42:170-185

118. Vander Wall SB, Jenkins SH (2003) Reciprocal pilferage and the evolution of food-hoarding behavior. Behav Ecol 14:656-667

119. Hamilton JE (1939) The leopard seal Hydrurga leptonyx (De Blainville). Discovery reports 18:239-264
120. DeVault TL, Rhodes JOE, Shivik JA (2003) Scavenging by vertebrates: behavioral, ecological, and evolutionary perspectives on an important energy transfer pathway in terrestrial ecosystems. Oikos 102:225-234

121. Borsa P (1990) Seasonal occurrence of the leopard seal, Hydrurga leptonyx, in the Kerguelen Islands. Can J Zool 68:405-408

Submit your next manuscript to BioMed Central and take full advantage of:

- Convenient online submission

- Thorough peer review

- No space constraints or color figure charges

- Immediate publication on acceptance

- Inclusion in PubMed, CAS, Scopus and Google Scholar

- Research which is freely available for redistribution

Submit your manuscript at

www.biomedcentral.com/submit

( Biomed Central 